\title{
La 'edad de los tiranos': una aproximación a las ambigüedades de la tiranía arcaica
}

\author{
César SierRa MARTín* \\ Universitat Autònoma de Barcelona \\ cesar.sierra@e-campus.uab.cat
}

Recibido: 10 de octubre de 2013

Aceptado: 12 de mayo de 2014

\section{RESUMEN}

En el presente trabajo abordaremos las tiranías arcaicas. Procesos históricos tradicionalmente englobados en complejas construcciones historiográficas, actualmente se muestran como resultado de las diferentes tensiones internas que salpicaron Grecia en la época arcaica. Por nuestra parte, resaltaremos la importancia de las relaciones personales para la instauración de algunas tiranías arcaicas a través de los casos de Clístenes, Cípselo, Cilón, Pisístrato y Lígdamis.

Palabras clave: Tiranías arcaicas. Pisístrato. Lígdamis. Cilón.

\section{The 'Age of Tyrants': an approach to the ambiguities of archaic tyranny}

\begin{abstract}
In this paper will address the archaic tyrannies. These historical processes in complex constructions traditionally encompassed historiography are currently displayed as a result of the different internal stresses that dotted Greece in the archaic period. For our part, we will highlight the importance of personal relationships for the establishment of certain archaic tyranny by Cylon cases, Pisistratus and Lygdamis.
\end{abstract}

Key words: Archaic Tyranny. Peisistratus. Lygdamis. Kylon.

Sumario: 1. La Grecia arcaica: etiquetas historiográficas. 2. Ortagóridas y Cipsélidas: las primeras dinastías tiránicas. 3. Teágenes de Mégara y su yerno, Cilón de Atenas. 4. Pisístrato y Lígdamis: futuros tiranos en el exilio. 5. Des-etiquetar la tiranía.

\footnotetext{
*Agradezco los comentarios y sugerencias que sobre este texto han realizado los profesores Jordi Cortadella y Ricardo Martínez Lacy, así como las correcciones propuestas por los evaluadores anónimos. Por descontado, los errores que pueda contener el trabajo son de mi autoría. Este trabajo está adscrito al proyecto RYC201005622.
} 


\section{La Grecia arcaica: etiquetas historiográficas}

En 1970 el ilustre helenista Moses Finley comenzó su disertación sobre la Grecia arcaica afirmando que ésta se caracteriza por dos fenómenos de especial relevancia: la expansión colonial y el surgimiento de la pólis. ${ }^{1}$ Sobre este último proceso señala que fue una tarea ardua, forjada a través de muchos años y repleta de disturbios internos que constituyeron la seña de identidad del periodo. ${ }^{2}$ Por las mismas fechas, en referencia a la Grecia arcaica, Anthony Andrewes define claramente tres etapas evolutivas en su política: monarquía, aristocracia y una última fase que podríamos llamar "gobierno constitucional". ${ }^{3}$ Siguiendo a Andrewes, en la famosa "etapa oscura", la monarquía griega había cedido paulatinamente ante el auge de la aristocracia, que se adueñó de la vida política griega. ${ }^{4}$ Así, los sucesores de los reyes serían los aristócratas que basaban el derecho de sucesión en el prestigio de sus familias y su calidad o valía personal, inherente a su nacimiento. ${ }^{5}$ Este grupo social controlaba los cultos religiosos y se organizaba en consejos, como el Areópago en Atenas, acaparando el poder político. Según Andrewes, la transición de la aristocracia a los gobiernos constitucionales es la que presenta mayor conflictividad. Tanto es así que, como etapa intermedia entre ambas, el autor sitúa la tiranía, que vendría a ser una especie de puente que no acababa de ser constitucional ni aristocrático. ${ }^{6}$ En 1981, G. E. M. de Ste. Croix recoge el mismo proceso, enfatizando el problema sobre las diferencias clasistas entre aristocracia y población sometida. Para Ste. Croix, los tiranos son figuras que rompen la hegemonía aristocrática, instaurando un gobierno personal y dictatorial. ${ }^{7}$ Previamente a la "Edad de los tiranos", ${ }^{8}$ Grecia estaba dominada por los reyes devoradores de regalos ( $\delta \omega \rho$ póx́or $\beta \alpha \sigma \lambda \lambda \tilde{\eta} \varsigma /$ dorophagoi basilēes), que vemos en Hesíodo ${ }^{9}$ (Trabajos y días 38-39; 220-221; 248-251 y 263-264). Sin embargo, el mismo Ste. Croix no hace más que utilizar sesgadamente a Hesíodo y ello lo podemos comprobar analizando en conjunto las palabras del poeta beocio (Trabajos y días 219-230). En este pasaje Hesíodo opone a los 'reyes devoradores de regalos', personajes notables que interpretan torticeramente las leyes y en beneficio propio, frente a los que otorgan veredictos justos, favoreciendo así a su ciudad. Por tanto, Hesíodo se

\footnotetext{
${ }^{1}$ FinLEY 1983, 105.

2 FinLEY 1983, 116-117.

3 Literalmente sería: "Greek Monarchy, Greek Aristocracy and Development of Greek Constitution" (ANDREWEs 1971, 9-16).

${ }^{4}$ El desarrollo que vamos a sintetizar se encuentra en ANDREWEs 1971, 9-19.

5 Esparta fue un caso excepcional en este supuesto periodo de transición hacia gobiernos despóticos, afianzándose una monarquía que hunde sus raíces en los gobiernos heroicos de Grecia, pero de esto ya se percató el propio Grote 1847, 7. Por su parte, MeiKsins Wood 2003, 276, se refiere a Esparta como "estado conquistador", que consiguió conservar la monarquía a través de la participación de los reyes en las instituciones.

6 Sobre el inicio de los estudios de la tiranía griega es imprescindible Libero 1996, 12

7 STE. CRoIX 1988, 329.

8 Por 'edad de los tiranos' se entiende desde el siglo VII a. C. hasta la expulsión de los Pisistrátidas (511/10 a.C.), v. Dillon - Garlan 2010, 256.

9 Ste. Croix 1988, 327. Meiksins Wood 2003, 282-283, denomina a esta nueva clase social "señores homéricos".
} 
refiere a los "reyes devoradores de regalos" con intención moralizante y quizás como recurso expositivo. Así, el pasaje no induce a pensar que Grecia se hallaba dominada por los que devoraban regalos sino que, simplemente, se contraponen dos figuras de gobernante, encarnadas en el justo y el injusto, sin predomino aparente de ninguna de ellas. Análogamente a este caso, pese a que uno de los temas centrales de la obra de Heródoto sea mostrar las consecuencias de la insolencia humana (de la v̌ $\beta p ı /$ hýbris), ello no quiere decir que toda Grecia se rigiera por la misma. ${ }^{10}$ Recogiendo este contexto histórico, la tradición historiográfica suele asociar el conflicto entre aristócratas y sectores de la población sin derechos políticos con un binomio protagonizado por dominantes y dominados. ${ }^{11}$ En el pasado siglo, estas tensiones sociales se abordaban

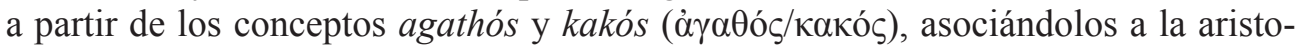
cracia y el pueblo, respectivamente. Este binomio se fundamenta normalmente en las palabras de los poetas arcaicos Teognis, Alceo y Solón, quienes reflejaron el contraste entre los valores de los agathoi: génos, riqueza, valor y justicia, sobre los defectos de los kakoi (por ejemplo, Teog. Elegías I. 525-526). ${ }^{12}$

A tenor del anterior contexto surgieron diferentes estudios acerca del origen social y el perfil de gobierno del tirano arcaico, destacando la dinámica económica en la Grecia arcaica y la violencia política como estandartes de estos incipientes regímenes políticos. Sin duda, este punto de vista tiene su origen en la clásica obra de Percy Ure de 1922, quien defendió una estrecha relación entre el surgimiento de los regímenes tiránicos y el florecimiento de una economía mercantil, resumido en una figura bautizada como "príncipe mercader". ${ }^{13}$ Por su parte, Santo Mazzarino sostiene una opinión que no difiere en gran medida de la propuesta por Ure pero que resalta el talante violento de los tiranos. Así, Mazzarino defiende que en Mileto se produjo una crisis aristocrática que facilitó la aparición de una figura que se abrió paso hacia el poder gracias a la violencia. A su vez Mazzarino indica que, constitucionalmente, la figura del tirano no puede precisarse con seguridad y que constituye un término popular que refleja un juicio de valor. Además señala que la figura del tirano es genuinamente griega, frente a los que enfatizaban su relación con el reino de Lidia esto es, el denominado "tirano lidio". ${ }^{14}$ Ciertamente, el punto de vista que combate Mazzarino

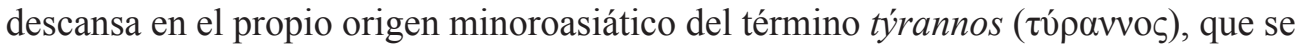
acuña en la cultura griega por primera vez en el famoso fragmento 25 de Arquíloco

10 Véase por ejemplo IMMERWAHR 1954, para la relación entre la hýbris humana y la acción histórica; SAÏD 2002, 139-140, argumenta que es un tema que comparte con la tragedia, y SIERRA 2011, 72-75, donde defendemos que es la piedra angular de la caracterización del mal gobernante.

11 EhrenBerg 1969, 19 y especialmente FouchARD 1997, 77-93, quien caracteriza las luchas políticas de la Grecia arcaica poniendo el acento en los conflictos entre aristócratas (dominadores) y el resto de cuerpo cívico (dominados), profundizando en conceptos como el valor (areté) y la consideración o prestigio social (timé).

12 Para profundizar en estas valoraciones véase CoBb-Stevens 1985, 110-161; Libero 1996, 33; LANE-Fox 2000, 35-51; Duplour 2006, 43; Plácido 2007, 134 y Wallace 2009, 412.

13 URE 1922, 3, para la relación entre auge económico y tiranía, y en la página 34, encontramos desarrollada la figura del "príncipe mercader". Véase el comentario historiográfico en STE. Croix 1988, 332.

14 Es decir, que la tiranía resulta una evolución política interna de la polis griega. MAZZARINO 1989, 193 199 y 235 y Musti 1989, 162. 
de Paros. ${ }^{15}$ En sintonía con los anteriores planteamientos, Claude Mossé señala que los tiranos accedieron al poder gracias a la aparición de nuevas formas de generar riqueza, centradas en el comercio intercomunitario. Bajo esta premisa analiza la tiranía de Trasibulo de Mileto, a principios del VI a.C. Según Mossé, la excepcional situación geopolítica de Mileto le permitía el control del comercio de grano entre el Mar Negro y Egipto, lo cual provocó el ascenso de un nuevo sector social que entró en pugna con el génos real. ${ }^{16}$ Así pues, la pregunta aún sigue en el aire ¿Cuál es el origen social y el perfil de gobierno del tirano arcaico? Muchas son las respuestas, tantas como aproximaciones historiográficas. Puede entenderse como un gobierno personal

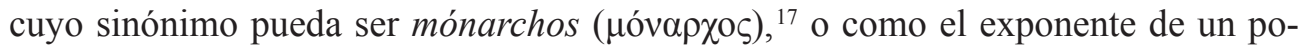
der absoluto superior al de los tradicionales basileis,${ }^{18} \mathrm{o}$ un déspota oriental, ${ }^{19} \mathrm{o}$ un líder popular. ${ }^{20}$ Lo cierto es que, como ha señalado recientemente Domingo Plácido, nuestra concepción de la tiranía como forma de poder personal está muy condicionada por las fuentes literarias de la época clásica, como Heródoto y Tucídides, por no hablar de las posteriores precisiones de Jenofonte o Aristóteles. ${ }^{21}$ En los últimos años asistimos a la deconstrucción del proceso histórico que abordábamos al inicio con las palabras de Andrewes, es decir: monarquía, aristocracia y gobierno constitucional. La misma existencia de las monarquías homéricas se ha puesto en cuestión pues el teórico proceso que iría desde la monarquía a la aristocracia descansa en un testimonio tan tardío como el de Aristóteles (Pol. 1285a). A buen seguro, los basileis hesiódicos hacen referencia a la propia aristocracia, es decir, a un colectivo sin rey. ${ }^{22}$ Cierto es que, en Aristóteles, apreciamos un esfuerzo por expresar de forma sintética los tipos de tiranía y cómo se hicieron con el poder, distinguiendo cuatro: el tirano que surge como demagogo, el que se alza con la tiranía desde un cargo público tras aprovechar algún disturbio, el que aprovecha el deterioro de la realeza y el que se escinde de la oligarquía. ${ }^{23}$ Pese a los modelos aristotélicos, estudios recientes destacan que las denominadas "revoluciones tiránicas" respondían a contextos sociales particulares

\footnotetext{
15 Véase discusión sobre el término en Chantraine 1968, 1146; Mossé 1969, 11; Mustr 1989, 161; Jufresa - FAU 2007, 98 y Plácido 2007, 136. Por otra parte, Libero 1996, 24-25, analiza el impacto en el ideario griego de la figura del tirano mostrada por Arquíloco.

16 Teoría desarrollada en Mossé 1969, 12-13.

17 JuFreSA - FAu 2007, 99.

18 Musti 1989, 161.

19 Idea de orígenes remotos Grote 1847, 5-8, y recientemente Plácido 2007, 135.

20 El caso paradigmático de la historiografía clásica es Pisístrato, recogido en Aristóteles ( Pol. 1305a 7-24, 1310 b 30) donde se asocia al tirano con el liderazgo popular. FinLEY 1983, 122.

21 Finley 1983, 122; Plácido 2007, 130-131 y MartíneZ-Lacy 2011, 48. Véase especialmente el pasaje de Heródoto donde se discuten las distintas formas de poder político (Hdt. III. 80-82) y análisis en WATERS 1971, 11.

22 Martínez-Lacy 2011, 49, valorando impresiones de Robin Osborne (Osborne 1996, 151). Por otro lado, se puede ampliar el análisis sobre el basileús hesiódico y homérico en la reciente síntesis de Ch. Ulf (Ulf 2009, 88 y ss. para la figura del basileús homérico e $I D .2009,91$ y ss. para el hesiódico) toda ella con bibliografía actualizada. Asimismo, encontramos muy recomendable la aproximación histórica de Fouchard 1997, 25-56.

23 Arist. Pol. 1305a6ss, 1308a19ss, 1310b12ss. Resumen de la posición aristotélica en SteIN-HöLKesKamp 2009, 101.
} 
y cada gobierno tiránico tenía su propia idiosincrasia. ${ }^{24}$ Todo ello viene a cuestionar un modelo unívoco que simplifique la historia de la Grecia arcaica bajo el binomio demos/oligarquía. ${ }^{25}$ En consecuencia, cada caso particular adquiere una notable complejidad de estudio y la tiranía arcaica se presenta actualmente como fruto de las circunstancias históricas y no una etapa de tránsito hacia regímenes constitucionales. ${ }^{26}$

Sin embargo, pese a los esfuerzos por revertir esta dinámica, en la actualidad estas etiquetas aún tienen vigencia en el análisis historiográfico de la tiranía griega. Recientemente, E. Meyer se acerca al concepto de tiranía a través del famoso excurso de Tucídides sobre la caída de Hipias en Atenas (Th. VI. 53-59). La autora puntualiza, siempre siguiendo a Tucídides, que tras la muerte de Hiparco el gobierno de su hermano Hipias se convirtió en una auténtica tiranía, esto es, injusta, cruel y violenta. ${ }^{27}$ Vale la pena volver a reflexionar sobre esta noción de 'auténtica tiranía' pues sobreponerse a esta imagen de un gobierno ilegal, injusto, arbitrario y violento es complicado y, en contraposición, asumir que ciertas tiranías supusieron corrientes renovadoras es chocante. Louis Gernet advertía que la tiranía griega presenta dos caras: una en cuanto a noción de estado basado en un poder personal y otra relacionada con el carácter renovador del gobierno tiránico. ${ }^{28}$ No cabe duda de que la faceta más oscura de la tiranía es la que más éxito ha tenido a lo largo de la historia y los distintos modelos interpretativos que hemos descrito así lo atestiguan. Cierto es que todas estas simplificaciones teóricas están parcialmente superadas entre los historiadores de la Antigüedad pero no así en otros muchos campos. Por ejemplo, en una reciente reflexión sobre teoría política se relaciona a nivel ideológico la tiranía griega con la dictadura romana, definiendo ambas como gobiernos ilegales, violentos y arbitrarios. ${ }^{29}$ En otro artículo reciente se recurre al mismo marco de trabajo donde la tiranía es el paso previo hacia la democracia o gobierno constitucional, rememorando la postura de A. Andrewes. ${ }^{30}$ Casos como los anteriores no basan sus argumentos en

24 KAllet 2003, 119-121 y, especialmente, Lewis 2009, 9-14, quien señala la distinta naturaleza del poder tiránico según el contexto histórico así como la influencia que tuvieron las Guerras Médicas sobre la concepción antigua del tirano.

25 En términos generales véase GEHRKE 1997, 459-461, quien sitúa la competencia entre la nobleza por el poder como el desencadenante de las tiranías.

26 Anderson 2005, 174-175, enfatiza que las tiranías constituyeron pasos decisivos en la evolución política de las póleis arcaicas. Por ejemplo, a través de los estudios realizados por Miriam Valdés, puede percibirse la complejidad de la creación de la ciudadanía ateniense y cómo el gobierno tiránico tomó parte en dicho proceso (VALDÉs 2003). No obstante, algunas póleis no llegaron a gobiernos democráticos (Esparta) y otras pasaron de la aristocracia a la democracia (Corcira en el siglo V a.C.) por no hablar de las tiranías siciliotas. Todo ello no excluye que debamos ofrecer un análisis de conjunto sobre la tiranía como fenómeno político.

27 La intención de Tucídides era trazar un paralelismo entre los gobiernos tiránicos y la política de la Atenas de su tiempo MeYer 2008, 24.

28 Gernet 1980, 299.

29 El autor del trabajo nos advierte sobre la influencia de las dictaduras modernas en nuestro concepto de tiranía griega y dictadura romana (KALYVAS 2007, 412-413); pese a ello, creemos que no logra distanciarse de este enfoque y termina por asumir el cliché. Sin embargo es interesante su análisis de la adopción del estereotipo por parte de la cultura romana, a través de los testimonios de Dionisio de Halicarnaso y Apiano, ambos escritores griegos.

30 FLECK - HANSSEN 2013, 397, trabajo que no logra convencernos sobre su tesis principal que se basa en la ecuación: pólis costera - riqueza comercial - tiranía (de nuevo el 'príncipe mercader') y, tras la tiranía, sobreviene la democracia. Esta hipótesis no es nueva y hay póleis, como Egina, que no la cumplen. 
bibliografía anticuada sino en especialistas como Kurt Raaflaub y Robert Wallace, quienes recientemente recurrían a la vieja etiqueta de 'edad de los tiranos' e indicaban que las tiranías griegas fueron el paso previo hacia la democracia. ${ }^{31}$ Esta postura parte de la suposición de un démos inmaduro para asumir el gobierno y que, por tanto, precisa de un tutor que lo sumerja en una transición política violenta. ${ }^{32}$ Estas tendencias actuales encuentran su contraste en la reciente síntesis de E. Stein-Hölkeskamp donde se define a la tiranía arcaica como la culminación del gobierno aristocrático y no como una alternativa al mismo. Continúa la autora argumentando que las tiranías ayudaron a consolidar las estructuras sociales y económicas de la pólis arcaica y que, cuando éstas quedaron firmemente establecidas, la tiranía quedó obsoleta como forma de gobierno. ${ }^{33}$ Sin embargo, sostiene Stein-Hölkeskamp, el enfoque de la historiografía alrededor de la tiranía continúa siendo negativo pese a todos los matices que a menudo se introducen. ${ }^{34}$ No obstante, la autora supone que el desgaste de la tiranía arcaica tiene que ver en cierto modo con el advenimiento de la democracia en un análisis determinado por el caso ateniense..$^{35}$

Por nuestra parte, recogiendo el espíritu que quiere salir de las generalizaciones teóricas que encasillan el análisis de la tiranía griega, queremos reflexionar brevemente sobre la importancia de las relaciones personales, familiares y de amistad, en la instauración y consolidación de algunos gobiernos tiránicos. Concretamente, a continuación nos centraremos en la estrategia matrimonial seguida por los Ortagóridas y los Cipsélidas (primera mitad del VII a.C.), la relación entre Teágenes de Mégara y su yerno Cilón (segunda mitad del VII a.C.), y Pisístrato de Atenas y Lígdamis de Naxos a mediados del siglo VI a.C., pues entendemos que constituyen un buen ejemplo de cómo la suma de esfuerzos o sinergias fue de vital importancia para el éxito de las tiranías arcaicas. Finalmente, propondremos una breve reflexión sobre la vigencia de las categorías historiográficas que hemos descrito.

\section{Ortagóridas y Cipsélidas: las primeras dinastías tiránicas}

En la Argólide, en la ciudad de Sición, no muy lejos de Corinto, se instauró en la primera mitad del VII a.C. una tiranía, fundada quizás por Ortágoras, que perduró prácticamente un siglo. ${ }^{36}$ Previamente a la instauración de la tiranía de Clístenes, Sición poseía un gobierno de perfil aristocrático con magistraturas anuales (Pausanias II. 7). Según sabemos por fuentes más bien tardías -Heródoto (VI. 126), Aristóteles (Pol. 1315b 12), Plutarco (Mor. 553b) y Diodoro (VIII fr. 24) - fue la tiranía más du-

\footnotetext{
31 RaAflaub - Wallace 2007, 42-43.

32 En similares términos se pronuncia McGlew 1993, 115 que nos habla de la inocencia política que pierde el démos tras la tiranías.

33 Stein-HölKeSKAmp 2009, 114.

34 Stein-HölKesKamp 2009, 112.

35 Nótese como la autora comienza y acaba su reflexión aludiendo al caso ateniense y generalizando a partir del mismo (Stein-HöLKESKAMP 2009, 100 y 114). Ello da pie a que el lector interprete que tras la tiranía sobreviene la democracia y eso no se ajusta al panorama político griego.

36 Libero 1996, 181; Dillon - Garlan 2010, 259.
} 
radera de la historia de Grecia, lo cual despertó la atención de los autores antiguos. ${ }^{37}$ Concretamente, Aristóteles aborda la explicación de esta extraordinaria longevidad de la forma siguiente:

La tiranía que más tiempo duró fue la de Ortágoras y sus hijos en Sicione, que se mantuvo cien años. La causa de ello es que trataban a los súbditos con moderación y en muchas cosas estaban sometidos a las leyes. Además Clístenes, por ser de aptitudes guerreras, no era despreciable, y las más de las veces se ganaba al pueblo con sus atenciones. $^{38}$

En este pasaje, Aristóteles defiende que el modelo de tiranía Ortagórida era respetuosa con las leyes y con el démos de ahí que durara tanto. ${ }^{39}$ Entre otras cosas, el gobierno de Clístenes destacó por un suceso puntual relacionado con la boda de su hija Agarista. Al parecer, durante los Juegos Olímpicos del 572 a.C., Clístenes planteó una curiosa forma de casar a su hija, proclamando que aquel que se viera digno candidato acudiera a Sición al cabo de sesenta días. Según Heródoto (VI. 126. 2-130), llegaron numerosos pretendientes de toda la Hélade quienes debieron demostrar sus cualidades personales durante todo un año. Finalmente, Clístenes se decantó por el ateniense Megacles (Hdt. VI. 129. 2). Esta curiosa historia pone de manifiesto la voluntad de Clístenes de romper con los tradicionales y endogámicos lazos de solidaridad aristocráticos. ${ }^{40}$ La acción de Clístenes se produce en el mayor escaparate de la Hélade, los Juegos Olímpicos, proclamando a los cuatro vientos que en Sición no había ningún candidato idóneo para casarse con su hija. ${ }^{41}$ Así, el matrimonio de Agarista con Megacles certifica la unión entre dos familias de especial relevancia en la época arcaica como son los Ortagóridas en Sición y los Alcmeónidas en Atenas. ${ }^{42}$ En consecuencia, Clístenes reforzó su posición interna, al buscarse un yerno influyente, a la vez que estableció nuevos contactos exteriores. Todo ello hace que Heródoto sentencie que las maniobras matrimoniales y políticas de Clístenes condujeron a que los Ortagóridas sobresalieran en importancia y fama en toda la Hélade.

37 Comentario en Mossé 1969, 37-47, que caracteriza a Clístenes como un líder militar, y LEWIs 2009, 3-6.

38 Pol. 1315b 12; traducción de M. García Valdés, Aristóteles. Política, Madrid, Gredos, 2000.

39 Clístenes, vencedor de los Juegos Olímpicos, era descendiente de Mirón cuyo hermano, Ortágoras, da nombre a la dinastía. La genealogía de Clístenes y los Ortagóridas puede seguirse en Mossé 1969, 39-40, y LIBERO 1996, 181-182.

40 Dicha conducta endogámica se define en ANDrewes 1971, 12; FInLEY 1983, 115, y, recientemente, Duplouy 2006, 39-53.

41 Esta tendencia a buscar lazos matrimoniales fuera de la propia comunidad no es exclusiva de los Ortagóridas. Recientemente A. Duplouy ha señalado que los matrimonios concertados con familias extranjeras tenían fines militares y los denomina "exogamia cívica", resaltando los ejemplos de Megacles y Agarista; Cilón y la hija de Teágenes y Pisístrato con Timonasa (Duplouy 2006, 85). Bajo nuestro punto de vista, lo importante era la reciprocidad entre familias o particulares, pues el interés de las élites arcaicas trascendía el ámbito de la pólis. También es interesante la postura de Herman 2002, 10-13, alrededor de la amistad ritualizada o relaciones de reciprocidad entre individuos sin conexión previa; cuestión que abordaremos en el caso de Pisístrato y Lígdamis.

42 Pese a que algunos autores digan que el matrimonio favoreció más a la tiranía de Sición que a los Alcmeónidas (Mossé 1969, 38). Sobre la proximidad de los Alcmeónidas a las diferentes tiranías griegas y, en particular, a la de Pisístrato véase LAVELLE 2005, 3-5 y 221. 
Tras la mención a los Ortagóridas, Aristóteles refiere que la siguiente dinastía de tiranos más longeva fue la de los Cipsélidas en Corinto, con setenta y seis años ${ }^{43}$ (Pol. 1315b 3). Los integrantes de esta saga siguieron una estrategia contraria a la de Clístenes pues, según cuenta Heródoto (V. 92. 2. $\beta$ ), en Corinto gobernaban los Baquíadas, una dinastía que solía concertar sus matrimonios en el seno de su propia familia. ${ }^{44}$ Un miembro de esta familia, Anfión, tuvo una hija con un defecto físico, Labda, y por ello ningún Baquíada quería casarse con ella. Finalmente Eetión, un miembro importante de la localidad corintia de Petra, la desposó. Según el oráculo de Delfos, la descendencia de Labda se rebelaría contra los Baquíadas y haría justicia en Corinto.$^{45} \mathrm{El}$ aludido, Cípselo, fue objeto de las iras de los Baquíadas quienes fueron a casa de Labda con la intención de eliminar al recién nacido. Pero el destino, tan presente en la obra de Heródoto, se encargó de salvar milagrosamente a Cípselo, pues su madre lo escondió en una jarra, tomando así su nombre de esta anécdota. Llegada la edad adulta, Cípselo se convirtió en un personaje respetado entre el pueblo y llegó a participar en el gobierno de Corinto con el cargo de polemarco. Como los Baquíadas

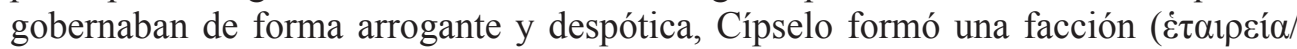
hetaireía) y tomó el poder asesinando a Hipoclides. ${ }^{46}$ Heródoto define su gobierno en estos términos:

Y, una vez erigido en tirano, he aquí la clase de hombre que fue Cípselo: desterró a muchos corintios, a otros muchos los privó de sus bienes, y a un número sensiblemente superior de la vida. ${ }^{47}$

Las palabras de Heródoto hacia Cípselo son contundentes. Sin duda esta es la figura tradicional de tirano, es decir, despótica y violenta. Sin embargo, éstas no dejan de ser las impresiones personales de Heródoto pues el mismo Aristóteles señala que el gobierno de Cípselo fue de carácter análogo al de Clístenes de Sición (Pol. 1315b 12. 3). Debemos atender también al dato que refiere el oráculo acerca de la liberación que suponía para Corinto la llegada al poder de Cípselo. ${ }^{48}$ Todo ello nos previene de seguir al pie de la letra la opinión de Heródoto respecto a Cípselo. ${ }^{49} \mathrm{Al}$ respecto, la historiografía moderna suele calificar a Cípselo como un "líder popular" puesto que gobernaba la ciudad sin necesidad de escolta. ${ }^{50}$ En cierto modo, los testimonios de los que disponemos nos presentan a un personaje que sigue la dinámica política de

43 Es la dinastía de los Baquíadas, que gobernó entre 658-585 a.C. según Dillon - GarLan 2010, 262.

44 Parece que los Baquíadas decidieron prescindir de una monarquía que ellos mismos controlaban, es decir, una aristocracia encubierta (Oоsт 1972, 10).

45 Heródoto reproduce literalmente el oráculo (Hdt. V. 92. 2. $\beta-\gamma$ ).

46 La versión de la llegada al poder de Cípselo únicamente se recoge en Nicolás de Damasco F57, traducción en Dillon - Garlan 2010, 264 y comentario crítico en Oost 1972, 10-11, quien realiza un paralelismo con los Tarquinios, tiranos de Roma. También debe verse PARKer 2007, 18-24, y LewIs 2009, 18 -20.

47 Hdt. V. 92. E. 2; traducción de C. Schrader, Heródoto. Historia, Madrid, Gredos, 1977.

48 WATERS 1971, 9, aduce que este tipo de oráculos reflejan los intereses populares.

49 Lewis 2009, 40-41, también nos advierte de la tendenciosidad de Heródoto en la presentación de los Cipsélidas.

50 Libero 1996, 141. 
su época, dividida en facciones enfrentadas, y que espera su oportunidad para alzarse con el poder.

De cualquier forma, Cípselo también representa una ruptura con la tradicional forma de establecer relaciones en el seno de los Baquíadas. La endogamia practicada por los Baquíadas en Corinto es una muestra de la tradicional forma de retener el poder político en manos de pocas personas y cualquier alteración era vista como un elemento de distorsión de su hegemonía. ${ }^{51}$ Así, en el mismo complot contra la vida del recién nacido Cípselo, los Baquíadas actúan corporativamente pues el peligro afecta a todos por igual. A partir de Cípselo, la tiranía recaerá hereditariamente en esta nueva rama familiar (de ahí el nombre de Cipsélidas): primero el hijo de Cípselo, Periandro, y luego el nieto, Psamético. No obstante, lo realmente importante es percibir cómo las estrategias de las élites aristocráticas variaban desde la exogamia de Clístenes hasta la endogamia de los Baquíadas. En ambos casos, estas incipientes dinastías tiránicas buscaban el correcto equilibrio interno y externo a través del cultivo de sus relaciones personales.

\section{Teágenes de Mégara y su yerno, Cilón de Atenas}

Tenemos pocos datos acerca de la tentativa de Cilón de conseguir la tiranía en Atenas entre los años 640-630 a.C. Heródoto (V. 71) y Tucídides (I. 126) son las principales fuentes y señalan que el ateniense Cilón, personaje de noble linaje y vencedor de los juegos olímpicos (640 a.C.), estaba emparentado con el tirano Teágenes de Mégara. ${ }^{52}$ Según Heródoto, Cilón se encaprichó de la tiranía y buscó apoyos en Atenas a fin de

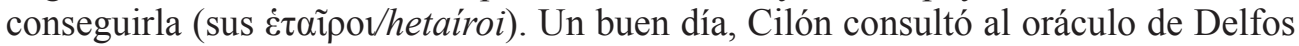
en relación a sus pretensiones y éste contestó que la ocasión idónea se le presentaría en la mayor fiesta de Zeus ${ }^{53}$ (Th. I. 126. 4). En este punto Tucídides refiere que Cilón interpretó lo siguiente:

Entonces él, tras obtener unas fuerzas de Teágenes y decidir a sus amigos, cuando llegaron las fiestas olímpicas del Peloponeso, ocupó la Acrópolis para instaurar la tiranía, creyendo que aquella era "la mayor fiesta de Zeus" y que en cierto modo tenía relación con él, que había sido un vencedor olímpico. ${ }^{54}$

El anterior pasaje plantea que algunas tiranías arcaicas se cimentaban gracias a relaciones personales y fuerzas foráneas que procuraban medios militares y económicos. Sin embargo, este caso no llegó a impulsar a Cilón hacia la tiranía puesto que los atenienses reaccionaron adversamente a sus intereses. Según parece, los atenienses

51 Según Gernet 1980, 304, la anómala boda de Labda en el seno de otra familia es el germen de la tiranía.

52 Sobre este tirano arcaico escribe Teognis de Mégara (Plácido 2007, 135).

53 Nótense las similitudes entre los relatos del ascenso al poder de Cípselo y Cilón. Ambos son personalidades relevantes en su ciudad que ambicionan el poder personal y se encargan de buscar apoyos, internos y externos, para conseguir su objetivo.

54 Th. I. 126. 5; traducción de J. J. Torres Esbarranch, Tucídides. Historia de la Guerra del Peloponeso, Madrid, Gredos, 2000. 
acudieron armados desde el campo y consiguieron sitiar a las fuerzas de Cilón en la Acrópolis, quien pudo escapar y vio frustrado su proyecto. ${ }^{55}$ Siguiendo a Tucídides, los seguidores de Cilón se acogieron como suplicantes mientras los atenienses que habían acudido del campo, dejaron el control de la situación a los arcontes. Entonces el Alcmeónida Megacles, arconte polemarco, permitió que dichos suplicantes fueran ajusticiados en contra de las leyes religiosas, constituyendo el origen de la "maldición de los Alcmeónidas". La conspiración de Cilón es más conocida por este suceso que por otra cosa aunque, como ha señalado M. Lang, resulta interesante contrastar las versiones que ofrecen Heródoto y Tucídides. El primero, debido a su cercanía con los Alcmeónidas, refiere una versión que suaviza la responsabilidad de Megacles, mientras que Tucídides lo acusa directamente. ${ }^{56}$

Ante la ocasión que brinda la presencia de estas dos versiones, permítasenos razonar sobre un problema de mayor importancia: el estudio de las tiranías arcaicas a través de las fuentes de la época clásica. En este sentido, resulta una gran contrariedad acercarnos a figuras tan interesantes como Cilón bajo la óptica negativa que Heródoto y Tucídides presentan de la tiranía. Como repetidas veces se ha puesto de manifiesto, durante el siglo V a.C., la figura del tirano pasa a adquirir una serie de connotaciones negativas que la aproximan incluso a las monarquías orientales. Tanto es así que el mismo Tucídides señala cómo la arché alcanzada por el démos en la

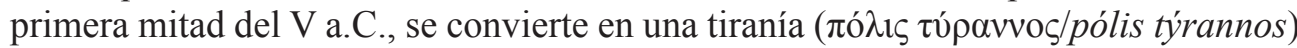
para los aliados de la Liga de Delos (Th. II. 63. 2) ${ }^{57}$ También debemos tener presente la experiencia personal de Heródoto con la tiranía. Como es sabido, Paniasis, quizás tío o primo de Heródoto, participó en un complot para derrocar al tirano Lígdamis de Halicarnaso. ${ }^{58}$ La tentativa resultó fallida y la familia de Heródoto partió al exilio. No cabe duda de que el anterior episodio debió marcar la impresión de Heródoto sobre las tiranías aunque ciertos estudios advierten que en la Historia se dan tanto imágenes positivas como negativas de monarcas y tiranos. ${ }^{59}$ La dura experiencia de las guerras médicas produjo en el ideario griego una asociación de la figura del tirano, como poder unipersonal, con las monarquías orientales, condicionando la interpretación de los tiranos arcaicos. ${ }^{60}$ De hecho, esta asociación entre monarquía oriental y tiranía termina por deteriorar la imagen del tirano y conferirle un aura de despotismo arbitrario y caprichoso. ${ }^{61}$

\footnotetext{
55 Según Libero 1996, 46, fueron los rivales aristocráticos de Cilón quienes le sitiaron.

56 Al parecer, ambas versiones parten de dos fuentes distintas. La de Heródoto debe ser Alcmeónida mientras que Tucídides, nuestra principal fuente para el suceso, podría estar vertiendo una interpretación personal. Véase LANG 1967, 243, y bibliografía en HorNBLOWER 1991, 202-211.

57 Kallet 2003, 120 y Meyer 2008.

58 Véase el asunto en Mazzarino 1974, 186-187; Masaracchia 1998, 270, y Marincola 2001, 21.

59 Gammie 1986, 187-195; Cawkwell 1995, 74, confía en el método de Heródoto, Gray 1996 y Forsdyke 2006, 236

60 PARKER 2007, 15-16; PlÁCIDO 2007, 135-135, y Lewis 2009, 11. Contrástese la impresión negativa sobre la tiranía en los historiadores mencionados con los testimonios contemporáneos de la tragedia Ática (KALLET 2003, 117-120).

${ }^{61}$ Lo cual tuvo repercusión en la historiografía que como mínimo desde G. Grote señala que Cilón era un déspota adinerado y presuntuoso que aspiró a la tiranía sin apoyo popular y movido por la aventura (GROTE 1847, 25).
} 
Por los motivos anteriores, el episodio de Cilón suele interpretarse como un intento de usurpación. ${ }^{62} \mathrm{El}$ principal argumento que esgrimen algunos historiadores es que, en la obra de Tucídides, el relato sobre Cilón se sitúa como precedente del excurso sobre Pausanias y Temístocles, interpretándose como una digresión sobre tres traidores $^{63}$ (Th. I. 128-138). Nada más lejos de la realidad puesto que, para Tucídides, Temístocles fue un líder visionario que propició grandes favores a su ciudad ${ }^{64}$ ( $\mathrm{Th}$. 138. 3). Por otro lado, no encontramos base suficiente para identificar a Cilón como un traidor sino que seguía una conducta facciosa. Dicho de otro modo, no parece que Cilón fuera a entregar Atenas a su suegro sino que parecía representar los intereses de una facción política concreta.

Sin embargo, podemos extraer con seguridad ciertos datos sobre la conspiración de Cilón: sus buenas relaciones con la aristocracia ateniense y megarense en contraste con un apoyo popular insuficiente. Sobre la primera cuestión podemos afirmar que, tanto Heródoto como Tucídides, refieren que Cilón estaba bien relacionado internamente, con sus hetairoi, y externamente con su suegro Teágenes ${ }^{65}$ En cuanto al apoyo popular, Plutarco (Sol. 12. 2) señala que, tras el episodio de Cilón, los atenienses se dividieron entre partidarios y detractores de Megacles. Así, la tentativa de Cilón pone al descubierto los conflictos entre la clase dominante de Atenas y entre ésta y el démos, abriendo una crisis política que no encontrará salida hasta las reformas de Solón. Al respecto, es muy interesante considerar el trabajo de Miriam Valdés, que analiza la procedencia geográfica de los aristócratas implicados en el conflicto y apunta hacia un problema en la participación política vinculado a la limitación al acceso a ciertas magistraturas de la aristocracia procedente de la zona central del Ática. ${ }^{66}$ Toda esta confusión fue aprovechada por Teágenes para contraatacar y tomar el puerto de Nisea y la isla de Salamina. Bajo nuestro punto de vista, la stásis interna que refiere Plutarco es anterior al golpe de Cilón, y no producida por un capricho de éste como indica Heródoto. En este sentido, debía existir un clima de tensión política que propiciase el golpe, aunque Cilón no contara finalmente con los apoyos internos suficientes. ${ }^{67}$ Finalmente, todo ello derivó en la mancha religiosa sobre los Alcmeónidas, en la pérdida de territorios a manos de los megarenses y en la purificación final de Atenas para expiar sus faltas. ${ }^{68}$ Por tanto, se puede realizar la lectura contraria a la tradición antigua y moderna sobre Cilón, destacando que su intento de tiranía venía a poner orden entre unas facciones que estaban abusando de su poder y conduciendo a

$62 \mathrm{O}$ un atentado como sugiere repetidas veces VALDÉs 2002.

63 JORDAN 1986, 143.

64 Véase este punto de vista en PodLecki 1975, 67-75 y Sierra 2011, 84.

65 LiBERo 1996, 45.

66 Todo ello tiene relación con el sinecismo de principios del VII a.C. que si bien supuso un pacto o consenso entre la nobleza, quizás no fue un éxito en cuanto al reparto del poder político (VALDÉs 2002,78 y Ss.).

67 Opinión que compartimos con CAWKWEll 1995, 85. Por su parte Herman 2002, 150, señala a Cilón y sus compañeros como un caso paradigmático de una conducta facciosa, donde los xenoi se congregan alrededor de un líder formando un pequeño núcleo que tiene apoyos en el exterior y en las clases bajas.

68 Plutarco, Sol. 12. 6, recoge la purificación de Atenas a cargo de Epiménides de Festo. 
Atenas por el mal camino. ${ }^{69}$ El episodio de Cilón sería una buena muestra de la solidaridad existente entre familias aristocráticas en la época arcaica. ${ }^{70}$

\section{Pisístrato y Lígdamis: futuros tiranos en el exilio}

En el famoso excurso de Heródoto sobre el gobierno tiránico en Atenas (Hdt. I. 5964), se refiere que Pisístrato tenía el objetivo claro de convertirse en tirano (al igual que Cilón). Según sabemos por dicho excurso, Pisístrato lideraba una facción política, la de los montañeses, creada ex profeso para alcanzar la tiranía, desplazando del poder a Megacles, líder de la costa, y a Licurgo, dirigente de la llanura ${ }^{71}$ (Hdt. I. 59. 3). En esta tesitura, Pisístrato y sus seguidores se sublevaron y tomaron la Acrópolis, apoderándose del gobierno de Atenas en una situación que evoca el golpe de Clístenes, Cilón y sus respectivos hetaíroi ${ }^{72}$ Continúa Heródoto refiriendo que, no mucho tiempo después, las facciones de Megacles y Licurgo se pusieron de acuerdo para expulsar a Pisístrato, perdiendo éste la tiranía al no estar firmemente establecido (Hdt. I. 60). La simple exposición de los hechos ya nos previene de considerar la arquetípica imagen de Pisístrato como un líder de amplio apoyo popular, pues necesitó de varios intentos para hacerse con el poder, lo cual subraya que las facciones de Megacles y Licurgo también contarían con apoyos considerables.

Sin embargo, el propio Megacles fue el responsable de la "segunda tiranía" de Pisístrato. Al parecer, Megacles tuvo sus diferencias dentro de su propia facción y por ello propuso a Pisístrato la tiranía de Atenas, a cambio de que sellaran su alianza política mediante el matrimonio del tirano con una de sus hijas. ${ }^{73}$ Pero la cuestión de cómo volver a la ciudad de una forma legítima era un asunto preocupante que finalmente se resolvió de una manera algo teatral:

En el demo de Peania había una mujer, cuyo nombre era Fía, de cuatro codos menos tres dedos de estatura y, además, agraciada. Ataviaron a la mujer en cuestión con una armadura de hoplita, la hicieron subir a un carro, le indicaron la actitud que debía adoptar para aparentar mayor majestuosidad y la condujeron a la ciudad, enviando por

69 Es el punto de vista positivo sobre la tiranía KALlet 2003, 119 y Wallace 2009, 415, que se apoya en los versos de Teognis para llegar a esta misma conclusión. Más bibliografía sobre el tema en VALDÉs 2002, 74, n. 34 .

70 Plécido 2007, 135.

71 El panorama político en la Atenas de esta época según la interpretación clásica puede resumirse así: Megacles representaría los intereses de los armadores y comerciantes, Licurgo haría lo propio respecto a los terratenientes y Pisístrato sería el líder de los pastores y los jornaleros. Actualmente se interpreta que estos 'partidos' que Heródoto refiere responden a la mítica división del Ática que realizaron los tres hijos de Pandión (el abuelo de Teseo) y que concuerda muy bien con esta división geográfica (v. VALDÉs - PLÁCIDO 1998, 9192, también VALDÉS 2002, 68, n. 10); por su parte, Brian M. Lavelle sugiere que esta división no encaja bien como contexto político entre las reformas de Solón y las de Clístenes y puede ser parte de una invención propagandística en un momento de fuertes tensiones políticas con Mégara, que había invadido el puerto de Nisea (Lavelle 2005, 219-220). Para más bibliografía y comentarios críticos véanse Holladay 1977, 40-42, y Asheri - Lloyd - CoRCElla 2007, 121.

72 En este punto recomendamos encarecidamente el trabajo de HolLADAY 1977.

73 Duplouy 2006, 90-91, destaca este matrimonio como una estrategia de reconocimiento social. 
delante heraldos que, al llegar a Atenas, proclamaron lo que les había sido ordenado, diciendo así: "Atenienses, acoged con propicia disposición a Pisístrato, a quien la propia Atenea, honrándolo más que a hombre alguno, repatría a su acrópolis". ${ }^{74}$

El propio Heródoto muestra sus reticencias a aceptar esta versión, ofreciendo en este caso su sinceridad como historiador ${ }^{75}$ (Hdt. I. 60. 3). Existe consenso entre la historiografía al señalar que este episodio se confunde con la posterior victoria de Pisístrato sobre sus opositores en las cercanías del demo de Pelene. ${ }^{76}$ Podríamos estar ante un episodio propagandístico y distorsionado orientado a justificar el gobierno del tirano a través de la conexión con Atenea, la diosa tutelar. ${ }^{77}$ Tras el episodio protagonizado por Fía, Heródoto refiere que Pisístrato no quiso tener tratos carnales con la hija de Megacles y éste, enterado de ello, conspiró para derrocar de nuevo al tirano, que volvió a exiliarse (Hdt. I. 61. 1-2). El acto de repudio suponía para Megacles toda una declaración de intenciones políticas por parte de su yerno quien no vería clara su posición en esta alianza. ${ }^{78}$

El ascenso a la tiranía de Pisístrato necesitó de un "tercer intento". Sabemos por Heródoto que Pisístrato pasó en el exilio cerca de once años, lo cual nos induce a pensar de nuevo en un matiz al perfil popular de Pisístrato ${ }^{79}$ (Hdt. I. 62 y Arist. Ath. 15. 3). En esta ocasión, Pisístrato se hallaba refugiado en Eretria, pólis de la isla de Eubea, tramando lo siguiente:

Prevaleció la opinión de Hipias de volver a recobrar la tiranía y, por ello, se dedicaron a reunir donativos de las ciudades que, por lo que fuera, estaban en deuda con ellos. Y por cierto que, aunque fueron muchas las ciudades que contribuyeron con grandes sumas, los tebanos superaron a todos en la aportación de dinero. Luego, por decirlo en pocas palabras, pasó el tiempo y lo tuvieron todo a punto para el regreso, pues hasta llegaron del Peloponeso mercenarios argivos, y un natural de Naxos, cuyo nombre era Lígdamis, que se les había unido voluntariamente, ponía un particular empeño, procurando dinero y hombres. ${ }^{80}$

El pasaje aporta datos valiosos. Por un lado, podemos apreciar que la vuelta de Pisístrato al poder se lleva a cabo gracias al dinero obtenido merced a las relaciones de proxenía, fuerzas militares y otras sinergias externas a la propia Atenas. En este tipo de situación, las amistades y relaciones de solidaridad se erigen como un factor

74 Hdt. I. 60. 4.

75 Aunque la versión se recoge también en Aristóteles (Ath. 14. 4).

76 Rose 1940, 81, y ASHER - LlOYd - CORCELla 2007, 122-123, señalan que puede ser la racionalización de un episodio anecdótico y que, seguramente, hubo un único exilio de Pisístrato.

77 El episodio protagonizado por Fía ha sugerido multitud de opiniones alrededor del significado de esta peculiar procesión. No nos detendremos en ello pero sugerimos la lectura de LAVELLE 2005, 99-107, que recoge las principales interpretaciones y ofrece una buena selección bibliográfica.

78 Vuelve a ser significativa la importancia de las relaciones personales en el ejercicio del poder, pese a que el episodio sea de dudosa historicidad.

79 Sobre la cronología de la trayectoria de Pisístrato no hay consenso entre la historiografía pero véanse las aproximaciones de HiND 1974, y la más reciente de LAVELLE 2005, 210-218.

80 Hdt. I. 61. 3-4. 
determinante. En primer lugar, destacan las deudas y otras obligaciones que parecen tener los distintos gobiernos (no sabemos si a título personal o público) con la familia del tirano, que redunda de nuevo en la solidaridad entre élites. En este sentido, destaca la maniobra matrimonial de Pisístrato con Timonasa, hija de Górgilo, personaje conectado con los Cipsélidas de Corinto que le aseguraba un punto de apoyo similar al que en su día tuvo Clístenes con Megacles y Cilón con Teágenes (Arist. Ath. 17. 4). En segundo lugar, y a título personal, sobresale la figura del naxio Lígdamis, quien parece muy cercano al tirano ateniense y su familia puesto que es el único que se menciona por su nombre en el pasaje ${ }^{81}$ La actuación de Lígdamis es notoria y habla por sí misma de su posición social y económica ya que aportaba dinero y hombres ${ }^{82}$

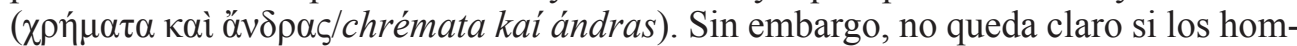

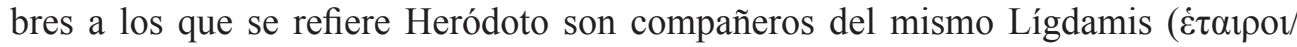
hetaíroi) o mercenarios contratados por éste; pero lo que sí se puede intuir es que Lígdamis se encontraba en una situación política similar a la de Pisístrato. En cierto modo, once años en el exilio son margen más que suficiente para trazar redes clientelares de este tipo, aunque dichas maniobras inducen a pensar en un contexto social y político más complejo de lo que muestran los estereotipos antiguos y modernos sobre la llegada al poder de Pisístrato.

Una vez que Pisístrato llegó al Ática con todas sus fuerzas, Heródoto refiere cómo sus partidarios se le unieron para iniciar una ofensiva que terminaría por encumbrarlo definitivamente como tirano (Hdt. I. 62-64). Sin embargo, aprendiendo de sus errores, Pisístrato tomó rehenes de sus opositores para, mediante el chantaje, gobernar con mayor comodidad sobre Atenas, consiguiendo retener el poder con firmeza:

[...] y logró arraigar la tiranía, merced a sus muchos mercenarios y a la afluencia de fondos, procedentes, en parte, del Ática y, en parte, del río Estrimón; asimismo, tomó como rehenes a los hijos de los atenienses que habían huido enseguida y los condujo a Naxos (pues Pisístrato había conquistado también la isla por la fuerza de las armas y había confiado su gobierno a Lígdamis) ${ }^{83}$

A raíz del anterior pasaje llegamos a la conclusión de que la tiranía de Pisístrato consiguió sustentarse merced a un equilibrio entre sinergias internas (del Ática) y externas (en Naxos y Tracia), ofreciendo una imagen bien distinta a la del líder popular que la tradición historiográfica sostuvo. Este argumento contraviene una imagen del

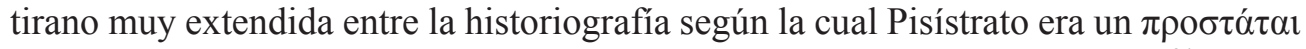

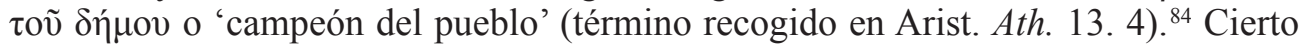
es que el apoyo ateniense de Pisístrato bien podía provenir de los sectores más des-

81 Sobre la figura de Lígdamis existe poca bibliografía al no haber muchas más fuentes en la literatura. Las principales referencias son: Mossé 1969, 20-22; CostA 1996; Libero 1996, 236-243, y, recientemente, SierRa - CORTADELla 2012.

82 Mossé 1969, 21, interpreta que Lígdamis fue un "tirano demagogo” cuya tiranía responde al modelo de las "tiranías jonias", caracterizadas por surgir en contextos de prosperidad económica. Demasiadas etiquetas para tan poca información.

83 Hdt. I. 64. 1.

84 Véase especialmente GoušchIN 1999, 22-23. 
favorecidos de Atenas pero subrayamos que ello no fue suficiente para mantenerlo en el gobierno y entendemos que no fue hasta la suma de apoyos externos cuando finalmente Pisístrato se alzó con la tiranía. En cualquier caso, ambas interpretaciones no son incompatibles. En este sentido, si volvemos la mirada a la interpretación del anterior pasaje en el clásico de Percy Ure, encontramos a un Pisístrato populista, financiado gracias a la propiedad de una mina en Tracia. ${ }^{85}$ Por nuestra parte, creemos que el pasaje no ofrece la posibilidad de asociar la persona de Pisístrato con un "tirano demagogo" o un "príncipe mercader" pues las referencias a las supuestas minas de Tracia no permiten precisar ni cronológicamente ni cuantitativamente su explotación. ${ }^{86}$ La confusión a la hora de trazar el perfil personal y de gobierno de Pisístrato puede percibirse en las mismas fuentes. Por una parte, Plutarco (Sol. 29. 1) señala que los thetes apoyaban a Pisístrato, pues estaba en contra de los ricos, dibujando una figura de corte popular. Por su parte, Aristóteles destaca de Pisístrato su carácter amable y conciliador (Ath. 16 y Pol. 1315b). Por descontado, las anteriores consideraciones están marcadas por el contexto social que las vio nacer, como ha señalado Claude Mossé, pero no dejan de mostrar la dificultad a la hora de precisar constitucionalmente y psicológicamente el perfil de las tiranías arcaicas. ${ }^{87}$

Por otra parte, en el pasaje de Heródoto resulta notable la interesante colaboración entre particulares, basada en la idea del favor recíproco ${ }^{88}$ Podemos creer la versión de Heródoto, tal cual la hemos leído, o pensar que Pisístrato obtuvo la tiranía gracias a la ayuda entre otros de Lígdamis y que, a su vez, el tirano ateniense ayudó a su colega a proclamarse tirano en Naxos. ${ }^{89}$

En último lugar, queremos precisar que las instauraciones de las tiranías en Naxos y Atenas comportaron un destacable movimiento de represaliados. En el caso de Pisístrato, los hijos de sus opositores son retenidos en Naxos, mientras que en dicha isla observamos un movimiento similar (Arist. Oec. 1346b2): al parecer Lígdamis también intentó deshacerse de sus opositores, expropiando sus posesiones y exiliándolos aunque, a tenor de lo que sabemos por Aristóteles, cabe la posibilidad de que estemos ante una "vendetta" de Lígdamis. En definitiva, resulta especialmente relevante apreciar cómo Naxos y Atenas fueron presa de un movimiento fraguado desde

85 URE 1922, 36.

86 Opinión que compartimos con Mossé 1969, 66.

87 Mossé 1969, 138-145.

88 Como indica Herman 2002, 90-91, quien define la relación entre Pisístrato y Lígdamis como una "amistad ritualizada", es decir, una relación basada en el intercambio recíproco de bienes y servicios practicada por individuos de diferentes unidades sociales.

89 No coincidimos con la opinión de BERVE 1967, 78, según la cual, la tiranía naxia fue resultado exclusivo de la intervención de Pisístrato. Cierto es que, sin el concurso de Heródoto, poco o nada sabríamos del gobierno tiránico que dominó la isla de Naxos ya que sólo en ciertos pasajes de Aristóteles (Pol. 1305a41 y Ec. 1346b2) y en Ateneo (Deipn. VIII. 348A), se ofrecen algunos datos al respecto. Sobre el origen de la tiranía naxia, sólo Ateneo aporta alguna referencia, en una cita literal de Aristóteles en su desaparecida Constitución de los naxios. En este pasaje, únicamente se refiere la existencia de un conflicto previo entre el pueblo naxio y ciertos poderes locales (una stásis). En esta tesitura parece que Lígdamis aprovechó el descontento para proclamarse tirano sin mencionar a Pisístrato. Berve no tiene en cuenta este pasaje de Ateneo por ello, siguiendo a Heródoto, otorga especial protagonismo a Pisístrato. Al respecto, Costa 1996, 158, y Consolo-LANGHer 1996, 121, n. 1, añaden que las fuentes del relato aristotélico sobre el origen de la tiranía pudieron ser fruto de la tradición local. Véase una interpretación general sobre el encumbramiento de Lígdamis como tirano en SiERRA - CoRTADELLA 2012. 
el exterior y cimentado en una serie de colaboraciones personales, que acabaron por decantar el equilibrio político interno hacia la tiranía. ${ }^{00}$ Aceptando esta suposición, tanto Lígdamis como Pisístrato, deberían considerarse como personajes relevantes en su patria, con apoyo interno en el démos, que se habían puesto de acuerdo en el exilio para alzarse con el poder.

\section{Des-etiquetar la tiranía}

Según nuestra aproximación a las tiranías arcaicas, resulta complejo establecer un modelo de tiranía o un proceso global y sin fisuras que explique el teórico tránsito de la aristocracia a los gobiernos constitucionales, a la luz de las fuentes que tenemos. Todo ello conduce a la idea de que las tiranías arcaicas surgieron gracias a sus propias circunstancias históricas, alejándose de etiquetas historiográficas como los "devoradores de regalos", los "príncipes mercaderes", los "tiranos lidios" o los "señores homéricos". Esta misma tradición historiográfica, siguiendo fuentes como Heródoto, Tucídides y Aristóteles, señalaba que Clístenes de Sición fue un líder militar, Cípselo un tirano demagogo, Cilón un conspirador y Pisístrato un líder popular. Entendemos que estas etiquetas historiográficas no siguen el contexto histórico pues, según hemos mostrado, la stásis entre élites dirigentes, entre éstas y el démos, y una conducta política facciosa parecen los factores adecuados para abordar las tiranías arcaicas. Así, los conflictos civiles propios de la Grecia arcaica a los que aludía Finley generan la posibilidad de instaurar un gobierno unipersonal, sin aparentes connotaciones negativas hasta las guerras médicas. En este sentido, creemos que no tenemos argumentos suficientes para sostener calificativos tales como usurpador o traidor en referencia a Cilón, ni para señalar al gobierno de Pisístrato como inconstitucional, violento y populista (o al menos más que el de sus opositores). En cualquier caso, no vemos argumentos de peso para afirmar que las tiranías arcaicas obraran al margen de las leyes, como vemos en las referencias aristotélicas a los gobiernos de Clístenes y Cípselo.

A través de los casos concretos que sucintamente hemos analizado, pensamos que generalizar sobre la tiranía arcaica constituye un terreno resbaladizo y más si aceptamos ciertos prejuicios fuertemente enraizados en la historiografía actual. Por otra parte, hay rasgos que sí merecen un análisis general, como la importancia de las relaciones personales en la instauración de las tiranías arcaicas. ${ }^{91}$ En los casos que hemos abordado observamos un esfuerzo por trazar redes y lazos de solidaridad, bien sean familiares o de amistad. En las tiranías más antiguas, Sición y Corinto, observamos estrategias matrimoniales contrapuestas, exogamia y endogamia respectivamente, pero con un mismo fin, asegurar la gobernabilidad de la tiranía. Otros casos, como el

90 A su vez, en un testimonio tardío del siglo II d.C. (Polieno 23. 2), se refiere cómo Polícrates obtuvo su tiranía gracias en parte a la intervención de soldados enviados por Lígdamis de Naxos. Únicamente en esta fuente encontramos el dato que resaltamos en conexión con el episodio de Pisístrato y que no desarrollamos por cuestiones de espacio.

91 Este punto se encuentra muy bien asimilado en la historiografía actual, véase por ejemplo DoPICO CAínzos 1998 y Duplouy 2006. 
de Cilón, no encontraron apoyos internos suficientes pese a la conexión con Mégara. Ciertamente, Pisístrato es el caso más paradigmático de la importancia de las relaciones personales. En primer lugar se casó con Timonasa para granjearse el favor de importantes familias argivas (Cipsélidas) y, en segundo lugar, aprovechó la ocasión para entablar una sólida amistad con Lígdamis, quien ayudaría a Pisístrato primero y luego recibiría la subsiguiente compensación al instaurarse como tirano en Naxos. Todo ello nos lleva a concluir que las estrategias familiares eran muy relevantes y notorias. ${ }^{92}$

La divergencia respecto a los modelos teóricos que presentábamos al inicio de la reflexión se agudiza todavía más si atendemos a los testimonios epigráficos. Por ejemplo, a través de un trabajo realizado por R. A. Santiago podemos acercarnos a la compleja situación interna de Quíos. ${ }^{93}$ En un epígrafe datado entre finales del siglo VII e inicios del VI a.C. (ML 8), se ha conservado una inscripción cuya intención era regular la convivencia pacífica en la isla. ${ }^{94}$ En el texto se hallan representados un poder central y otros de índole local, conectados o arbitrados por una Bulé Demosie en la que estaban representadas las comunidades regionales. ${ }^{95}$ Otra inscripción, cuyo estudio aborda la misma autora, nos traslada a la ciudad de Halicarnaso, en la primera mitad de V a.C., durante el gobierno del tirano Lígdamis ${ }^{96}\left(\right.$ Syll. ${ }^{3} 45=\mathrm{ML}$ 32). En este caso la inscripción es un documento público que refiere una alteración importante en el registro de la propiedad de la ciudad, otorgando fuerza legal a un personaje denominado Apolonides, cuyo padre casualmente se llamaba Lígdamis. Las disposiciones que contiene la inscripción parecen favorecer a la población caria (salmacita) que vivía en Halicarnaso, equiparando sus derechos de propiedad a los de la población griega. Como la propia autora refiere, la inscripción se ha interpretado de dos formas distintas: bien puede ser un acto de reconciliación social en un momento de debilidad de la tiranía o un acto de prepotencia del tirano frente a sus opositores. ${ }^{97}$ Otra inscripción cretense fechada a inicios del siglo V a.C. (SEG 27, 631), denominada 'contrato de Spensithios', hace referencia a los dones y privilegios otorgados a Spensithios $(\Sigma \pi \varepsilon v \sigma i \theta$ เo $)$ y sus descendientes, por sus labores como único escriba y registrador (o memorizador) de la comunidad (los dataleos), eximiéndole de impuestos, dotándole de un sueldo anual y de una donación en especie. Un caso muy parecido al de Spensithios lo hallamos en una inscripción chipriota conocida como 'bronce de Idalio' (SGDI 160$),{ }^{98}$ datado alrededor del 478-470 a.C. y que refiere los dones y privilegios que el rey de Idalio (Stasikypros) y los ciudadanos otorgan al médico Onasilos y su equipo por los servicios prestados durante el asedio de la ciudad por

\footnotetext{
92 Este tipo de relaciones matrimoniales y personales continuaron activas durante la época clásica como bien ha señalado Herman 2002, 142-156, analizando los casos de Pericles y el rey espartano Arquidamo; Alcifrón de Argos y el rey Agis de Esparta y Alcibíades y Endios de Esparta.

93 Hablamos del sugerente trabajo de SAntiago 1997.

94 SAntiago 1997, 35.

95 RoBINSON 1997, 90-101, sugiere a raíz de esto una organización democrática en la arcaica Quíos.

96 Edición del texto en Santiago 1996.

97 Santiago 1996, 635-638. No nos detendremos en los detalles de esta interesante inscripción pero remitimos al reciente y competente análisis de PIÑOL VILLANUEVA 2013a, con bibliografía.

98 Texto editado y traducido al francés en Samama 2003, 456 y ss.
} 
parte de los persas. Las condiciones son muy similares a las de Spensithios pero la peculiaridad radica en la equiparación jurídica entre el rey y los ciudadanos. ${ }^{99}$

Como podemos apreciar, los testimonios de primera mano de la época no dan pie alguno a elaborar un modelo o explicación global acerca del surgimiento de la pólis y el origen de las tiranías. En este sentido, hemos mostrado un ejemplo en Quíos que evidencia la voluntad de alcanzar un pacto ante un conflicto interno (stásis) y que sitúa a una Bulé Demosíe como árbitro y tribunal de apelación. Por otro lado, hemos valorado un ejemplo de gobierno tiránico en Halicarnaso, que podría apoyarse en una comunidad no-griega para reforzar su poder. También tenemos a un posible candidato a "devorador de regalos" en Creta, recibiendo diversos honores por los servicios prestados a la comunidad y, finalmente, el caso de una comunidad y su rey en Chipre que premian a un médico por sus servicios, mostrando una entente entre démos y basileús que transmite la idea de que las relaciones políticas entre ambas partes no siempre eran tensas. Con todo, la intención que tenemos al mencionar los anteriores ejemplos no es otra que poner de manifiesto la complejidad de abordar la historia de la época arcaica a partir de generalidades o etiquetas historiográficas y la necesidad de no apartarse en exceso de las fuentes.

\section{BIBLIOGRAFÍA}

ANDERson, G. (2005): "Before Turannoi Were Tyrants: Rethinking a Chapter of Early Greek History", Classical Antiquity 24/2, 173-222 (http://caliber.ucpress.net/doi/pdfplus/10.1525/ ca.2005.24.2.173? cookieSet=1).

Andrewes, A. (1971): The Greek Tyrants, London ( $1^{\mathrm{a}}$ ed. 1956, London).

Asheri, D. - Lloyd, A. - Corcella, A. (2007): A Commentary on Herodotus Books I-IV, Oxford.

Berve, H. (1967): Die Tyrannis bei den Griechen, München, vol. 1.

Cawkwell, G. L. (1995): "Early Greek Tyranny and the People", CQ 45/1, 73-86 (http:// dx.doi.org/10.1017/S0009838800041707).

Chantraine, P. (1968): “тúpavvos", [en] Dictionnaire Étymologique de la Langue Grecque. Histoire des Mots, Paris, vol. 4/1, 1146.

Cobb-Stevens, V. (1985): "Opposites, Reversals, and Ambiguities: the Unsettled World of Theognis", [en] T. Figueira - G. Nagy, (eds.), Theognis of Megara. Poetry and the Polis, Baltimore, 159-175.

Consolo Langher, S. N. (1996): "Naxos nell'Egeo arcaico e nella colonizzacione $<<$ calcidese >> dell'occidente", [en] E. Lanzillotta - D. Schillardi (eds.), La Cicladi e il mondo egeo. Seminario Internazionale di Studio 1992, Roma, 121-153.

Costa, V. (1996): "Ligdami, Pisistrato e la fondazione della tirannia", [en] E. Lanzillotta - D. Schillardi (eds.), Le Cicladi ed il mondo egeo. Seminario Internazionale di Studi 1992, Roma, 155-170.

99 Argumentado en EgETMEYER 1993, 49-50. Una discusión pormenorizada, rigurosa y documentada del ‘bronce de Idalio’ y del ‘contrato de Spensithios' la hallamos en Piñol Villanueva 2013, 127-131. 
Dillon, M. - Garlan, L. (2010): Ancient Greece. Social and Historical Documents from Archaic Times to the Death of Alexander the Great, London-New York (1 ${ }^{\mathrm{a}}$ ed. 1994, London-New York).

Dopico CAínzos, Ma D. (1998): "Entre lo público y lo privado: una contribución al estudio de la tiranía griega", ETF. Historia antigua 11, 119-136 (http://dx.doi.org/10.5944/ etf + ii.11.1998.4328).

Duplouy, A. (2006): Le Prestige des Élites. Recherches sur les modes de reconnaissance sociales en Grèce entre les $X^{e}$ et $V^{e}$ siècles avant J.-C., Paris.

Egetmeyer, M. (1993): “Zur kyprischen Bronze von Idalion”, Glotta 71, 39-59.

Ehrenberg, V. (1969): The Greek State, London (1 ${ }^{\mathrm{a}}$ ed. 1960, Oxford).

Finley, M. I. (1983): La Grecia Primitiva. Edad del Bronce y Era Arcaica, Barcelona (1 ${ }^{\mathrm{a}} \mathrm{ed}$. 1970, Cambridge).

Fleck, R. K. - Hanssen, F. A. (2013): "How Tyranny Paved the Way to Democracy: The Democratic Transition in Ancient Greece", Journal of Law and Economics 56/2, 389-416 (http://dx.doi.org/10.1086/670731).

ForsDyke, S. (2006): "Herodotus, political history and political thought", [en] C. Dewald - J. Marincola (eds.), The Cambridge Companion to Herodotus, New York, 224-241.

Fouchard, A. (1997): Aristocratie et démocratie. Idéologies et sociétés en Grèce ancienne, Besançon.

Gammie, J. G. (1986): "Herodotus on Kings and Tyrants: Objective Historiography or Conventional Portraiture?", Journal of Near Eastern Studies 45/3, 171-195 (http://dx.doi. org/10.1086/373186).

Gehrke, H. J. (1997): “La « stasis »”, [en] S. Settis (ed.), I Greci. Storia Cultura Arte Società, Torino, vol. 2/II, 453-480.

Gernet, L. (1980): Antropología de la Grecia Antigua, Madrid (1ª ed. 1968, Paris).

Goušchin, V. (1999): “Pisistratus' Leadership in A.P. 13. 4 and the Establishment of the Tyranny of 561/60 B. C.”, CQ 49/1, 14-23 (http://dx.doi.org/10.1093/cq/49.1.14).

GraY, V. J. (1996): "Herodotus and Images of Tyranny: The Tyrants of Corinth", AJPh 117/3, 361-389 (http://dx.doi.org/10.1353/ajp.1996.0047).

Grote, G. (2009): A History of Greece, New York, vol. 3 (1 ${ }^{\mathrm{a}} \mathrm{ed} .1847$, London).

Herman, G. (2002): Ritualised Friendship \& the Greek City, Cambridge (1 ${ }^{\mathrm{a}}$ ed. 1987, Cambridge).

Hind, J. G. F. (1974): “The 'Tyrannis' and the Exiles of Pisistratus”, CQ 24/1, 1-18. (http:// dx.doi.org/10.1017/S0009838800030184).

Holladay, J. (1977): “The Followers of Peisistratus”, G\&R 24/1, 40-56. (http://dx.doi. org/10.1017/S0017383500019628).

Hornblower, S. (1991): A Commentary on Thucydides, Oxford, vol. 1.

Immerwahr, H. R. (1954): "Historical action in Herodotus", TAPhA 85, 16-45 (http://dx.doi. org/10.2307/283465).

JordAn, B. (1986): "Religion in Thucydides", TAPhA 116, 119-147 (http://dx.doi. org/10.2307/283914).

Jufresa, M. - FAu, M. T. (2007): "La relación entre poeta y tirano en la Grecia arcaica", Nova Tellus 25/1, 95-116. 
Kallet, L. (2003): "Dēmos Tyrannos: Wealth, Power, and Economic Patronage", [en] K. A. Morgan (ed.), Popular Tyranny. Sovereignty and its Discontents in Ancient Greece, Austin, 117-153.

Kalyvas, A. (2007): “The Tyranny of Dictatorship: When the Greek Tyrant Met the Roman Dictator", Political Theory 35/4, 412-442 (http://dx.doi.org/10.1177/0090591707302208).

LAne Fox, R. (2000): “Theognis: an Alternative to Democracy”, [en] R. Brock - S. Hodkinson (eds.), Alternatives to Athens: Varieties of Political Organization and Community in Ancient Greece, Oxford, 35-51.

LANG, M. (1967): “Kylonian Conspiracy”, CPh 62/4, 243-249 (http://dx.doi. org/10.1086/365284).

Lavelle, B. M. (2005): Fame, Money, and Power. The Rise of Peisistratus and "Democratic" Tyranny at Athens, Ann Arbor.

LeAHY, D. M. (1957): “The Spartan Embassy to Lygdamis”, JHS 77/2, 272-275 (http://dx.doi. org/10.2307/629368).

LEwIS, S. (2009): Greek Tyranny, Exeter-Devon.

LiBero, L. (1996): Die archaische Tyrannis, Stuttgart.

Marincola, J. (2001): Greek Historians (=Greece \& Rome. New Surveys in the Classics 31), Oxford.

Martínez-Lacy, R. (2011): "Paola Vianello y la historia antigua", [en] S. Aquino - M. T. Galaz (eds.), La fascinación por la palabra. Homenaje a Paola Vianello, México, 47-52.

MasaracchiA, A. (1998): “Erodoto”, [en] G. D’Anna - M. Di Marco (eds.), Riflessioni Sull'antico. Studi sulla cultura greca, Pisa-Roma, 269-296.

MAZZARINO, S. (1974): Il Pensiero Storico Classico, Roma-Bari, vol. 1 (1ª ed. 1965, Bari). (1989): Fra Oriente e Occidente. Ricerche di storia greca arcaica, Milano (1 ${ }^{\mathrm{a}} \mathrm{ed} .1947$, Firenze).

McGlew, J. F. (1993): Tyranny and Political Culture in Ancient Greece, Ithaca.

Meiksins Wood, E. (2003): "La Polis y el Ciudadano-Campesino", [en] J. Gallego (ed.), El mundo rural en la Grecia antigua, Madrid, 269-326. (1 ${ }^{\mathrm{a}}$ ed. 1988, London).

Meyer, E. A. (2008): "Thucydides on Harmodius and Aristogeiton, Tyranny, and History", CQ 58/1, 13-34 (http://dx.doi.org/10.1017/S0009838808000025).

Mossé, C. (1969): La Tyrannie dans la Grèce Antique, Paris.

Musti, D. (1989): Storia Greca. Linee di sviluppo dall'età micenea all'età romana, Bari.

Oost, S. I. (1972): "Cypselus the Bacchiad", CPh 67/1, 10-30 (http://dx.doi. org/10.1086/365816).

Osborne, R. (1996): Greece in the making 1200-479 B. C., London.

PArker, V. (2007): “Tyrants and Lawgivers", [en] H. A. Shapiro (ed.), The Cambridge Companion to archaic Greece, Cambridge, 13-39.

Piñol Villanueva, A.

(2013): “Acceso de extranjeros a bienes inmuebles: primeros testimonios (siglos VIII-V a.C.)", [en] R. A. Santiago - M. Oller-Guzmán (eds.), Contacto de poblaciones y extranjería en el mundo griego antiguo. Estudio de fuentes (=Faventia Suppl. 2), Bellaterra, 113145. 
(2013a): "Halicarnaso y Salmacis. Historia de una comunidad greco-caria", [en] R. A. Santiago - M. Oller-Guzmán (eds.), Contacto de poblaciones y extranjería en el mundo griego antiguo. Estudio de fuentes (=Faventia Suppl. 2), Bellaterra, 169-185.

Plácido, D. (2007): "Las formas del poder personal: la monarquía, la realeza y la tiranía", Gerión 25/1, 127-166.

Podlecki, A. J. (1975): The life of Themistocles. A critical survey of the Literary and Archeological Evidence, Montreal.

RaAflaub, K. A. - Wallace, R. W. (2007): "People's Power and Egalitarian Trends", [en] K. A. Raaflaub - J. Ober - R. W. Wallace (eds.), Origins of Democracy in Ancient Greece, Berkeley, 22-48.

Robinson, E. W. (1997): The First Democracies. Early Popular Government Outside Athens, Stuttgart.

Rose, H. J. (1940): “Some Herodotean Rationalisms", CQ 34/1, $78-84$ (http://dx.doi. org/10.1017/S0009838800009149).

SAÏD, S. (2002): "Herodotus and Tragedy", [en] E. G. Bakker - I. J. F. de Jong - H. van Wees (eds.), Brill's Companion to Herodotus, Leiden, 117-147.

Sainte-Croix, G. E. M. DE (1988): La Lucha de Clases en el Mundo Griego Antiguo, Barcelona ( $1^{\mathrm{a}}$ ed. 1981, London).

Samama, E. (2003): Les Médecins dans le Monde Grec. Sources Épigraphiques sur la Naissance d'un corps Médical, Genève.

SAntiago, R. A.

(1996): “Ambigüedad en documentos públicos. Un temprano ejemplo en la epigrafía griega", [en] M. Puig Rodríguez-Escalona (ed.), Tradició Clàssica. Actes de l'XI Simposi de la Secció Catalana de la SEEC. St. Julià de Lòria-La Seu d'Urgell, 20-23 d'octubre de 1993, Andorra la Vella, 633-640.

(1997): “Algunos ejemplos de Realpolitik en las fuentes griegas", Faventia 19/2, 33-50.

Sierra, C. (2011): “Jerjes, Leónidas y Temístocles: modelos griegos en el relato de Heródoto", Historiae 8, 65-91.

Sierra, C. - Cortadella, J. (2012): “Telestágoras y la instauración de la tiranía en Naxos", Rivista di cultura classica e medioevale 54/2, 241-255.

Stein-Hölkeskamp, E. (2009): “The Tyrants”, [en] K. Raaflaub - H. van Wees (eds.), A companion to Archaic Greece, Oxford, 100-116.

Ulf, CH. (2009): “The World of Homer and Hesiod", [en] K. Raaflaub - H. van Wees (eds.), A companion to Archaic Greece, Oxford, 81-99.

URE, P. N. (1922): The Origin of Tyranny, Cambridge.

VALDÉS, M.

(2002): “Areópago y Prítanos ton naukraon: crisis política a finales del s. VII a.C. (de Cilón a Solón)", $D H A$ 28/2, 65-101.

(2003): "El Espacio Ciudadano: Integración/Exclusión en el imaginario y en la realidad ateniense del s. VI a.C.", SSHA 21, 29-45.

VAldÉs, M. - PlÁCIDO, D. (1998): "La frontera del territorio ateniense”, SSHA 16, 85-100.

Wallace, R. W. (2009): “Charismatic Leaders", [en] K. Raaflaub - H. van Wees (eds.), $A$ Companion to Archaic Greece, Oxford, 411-426.

Waters, K. W. (1971): Herodotus on Tyrants and Despots, Stuttgart. 